\title{
GOETHE'NIN TIYATROCULUĞU
}

\author{
Prof. Dr. Melahat ÖZGÜ
}

Yazınlarıyla kendisini dünyaya tanıtan, dehasiyle dünya yazinında kendisine bir yer sağlayan, 1732 yılında gözlerini dünyaya kapayan Almanların en büyük ozanı Johann Wolfgang von G o e t h e ozan olduğu oranda, tiyatrocu da idi. Onun gerçekten tiyatrocu olup olmadığı konusu üsrinde çok tartışıldı- Alman, dolayısiyle Avrupa tiyatro tarihçiliğinin gelişimi için önemli bir rol oynayıp oynamadığı, tiyatro alanında bir yenilik getirip getirmediği üzerinde çok duruldu. Goethe'nin tiyatro karşısındaki tutumu, tüm yaşamında: çocukluğundan olgunluk çağına değin araştırıldı, dramaturgi bakımından oyunları incelendi, sahne çalışmalari gözden geçirildi, kullandı

1. Goethe'nin çocukluğundan bu yana, tiyatroya karşı ateşli bir sevgi beslediği,

2. İçinde oyunculuk yeteneklerinin güçlü olduğu,

3. Dünya yazınina oyun dizelgesinde (repertoiarznda) düzenleyici bir rol oynadığı,

4. Oyunculuk kuramlarını, Almanya'da, ilk kez ortaya sürdüğü,

5. Oyuncuların hem eğittiği, hem yönettiği,

6. Eleştirici, yargılayicı ve etkileyici bir yönetici olduğu,

7. Ayni zamanda da sahne dekorlarının yaratıcısı, biçimlendiricisi olarak kendisini gösterdiği saptandı.

Goethe'nin, Thüringen-ilinin başkenti olan Weimar'daki tiyatro başarılarına nesnel olarak bakıldığında, olumlu olumsuz elde ettiklerinin etkisi, yalniz Alman dilini konuşan bölgelere değil, bir çok bakımdan tüm Avrupa'ya yayılmıştır.

Goethe, kendi yazdığı Dichtung und Wahrheit ("Şiir ve Hakikat") adlı özgeçmişinde, Büyükannesi'nin kendisine bir kukla tiyatrosu 
armağan ettiğini söyler. Bu kukla tiyatrosu da onu, daha ç o c u k $l \mathrm{u} \breve{\mathrm{g}}$ u n d a tiyatro müdürü ve oyun yöneticisi yaptı̆̆ını, kuklalarını oynatırken, çeşitli buluşlar elde ettiğini, oyun yeteneğini güçlendirdiğini, hayalgücünü artırdığını ve sahrelemede belli bir teknik kazandırdığını anlatır. Bütün bunlar, kendisine, onu tiyatroya götüren tohumlar ekmiş... Onun, bu tiyatro dünyasiyle ilk karş1laşması, yalniz seyirci olarak bırakmamiş, ayni zamanda kendisini büyük:bir istekle bu işe sokmuştur.

Çocuk Goethe, Prusya Kralı Büyük Friedrich'in, Ingilizlerle birleşerek Avusturya'ya, Maria Theresia'ya ve Fransa'ya karşı açtığı savaş içinde büyüdü. Savaş, tam yediyıl sürdü (1756-1763). Barıstan sonra da Frankfurt'a, Fransız oyuncu toplulukları geldi. Bunlarla, çocuk Goethe'nin, tiyatroya karşı olan ilgisi daha da arttı. Babası'nın; tiyatro ile hiç ilgisi yokmuş; ne zaman tiyatrodan söz edilse "hiç bir şeye götiürmez!" dermiş. Oğlu da Babası'na karşı tiyatroyu elinden geldiğince savunmaya çalışır, gördüğü oyunların tüm yabancı dillere çevrildiğini 'söýler, mutluluktaki kusurları, mutsuzluktaki erdemlerin sanatli bir doğrulukta dengeleyebildiğini anlatırmış. Seyrettiği Lessing'in Miss Sara Samson'unu, Lillo'nun Londra Taciri'ni örnek gösterir, Aristoteles'in "zaman, mekân ve eylem birliği"ne dayanan üçbirlik kuramı'nının olayları nasıl gerçekleştirdiğini açıklar ve çabucak öğrendiği Fransızcasiyle, Fransiz dramlarının kaynaklarını araştırır, Corneille ile Racine'in oyunlarına yazdıkları önsözleri okur, Fransız sahne biçimleriyle sahne düzenlerine ve Fransız dizeleri arasındaki uyumu, savunmasına katarmış

Frankfurt'da, Tiyatroseverler; ünlü bir ozan olan Adam Ölenschläger'in evinde biraraya gelip özel bir sahne kurarlar (17791850). Bu sahnede, kendi çaplarına göre oyunlar gösterirler. Racine’in Britanicus adlı oyunu sahnelenirken, Goethe, genç yaşta, heyecanını tutamaz, kendisi de Fransızlardan gördüklerini denemek ister ve oyunlara katılır. Oyunda da Goethe Nero rolünü oynar. Bir de Lessing'in Minna von Burnhelm'inde Wachtmeister (Başş̧avuş) rolünde oyunculuğunu gösterir. Bundan böyle Goethe'de, yöneticilik ve oyun yazarlı̆̆ için büyük bir heves uyanması doğaldı; çünkü tiyatronun anlamı ve etkisi için oyunların iyi yazılması ve iyi sahneye konması iyi de yönetilmesi gerektiğini Goethe, daha çocuk yaşlarında anlamıştı.

1 Goethe, Dichtung und Wahrheit 1. Buch, Artemis Vrlg. hrsg. Ernst Beutler, Zürich, Bd. 10, S. 20, 57-30, 119, 123, 332. 
Goethe çocukluğunda iyi bir seyirciydi. Frankfurt'da, Adam Ölenschläger'in evinde, amatör ruhla oynanan oyunlạr heyecanla seyrediyordu. $O$, bu heyecanmı sonraları Leipzig'de, Üniversitede hukuk okurken de sürdürdü. Burada, ünlü gezici Koch Topluluğu vardı. Bu toplulukta Goethe, meslek edinmiş oyuncularla tanıştı. Gerçi bunlar artık yerleşik olmuşlardı ama, hâlâ gezginci alışkanlıklarını bırakamamıslardı. Altı gün sonra da Bode'nin Richard Cumberland'den, Batı. Hintli' diye çevirdiği "The West Indien" adla oyunu oynadılar. Duygusal bir komedi idi but. Goethe, bunda başrolü oynadı. Oyun Hauptmann'ın evinde gösterilecekti; ama, yalnızca dört çift kulisle donatılmıs portatif sahne elverişli gelmedi. $\mathrm{Bu}$ yüzden de sahne genişletildi. Burada birbirlerine koşut boyutlar sözkonusu oldu; çünkü arka perde yalnızca 5,60 metre genişliğinde ve 4,20 metre yüksekliğindeydi. Değiştirilmelerin daha çabuk yapılabilmesi için de, dekorda, katlanılabilir tahtaperde kullanıldı; arkaperde de çekilir biçimde kuruldu.

Almanya'da, Gottsched ile Lessing'in aracıllğiyle, VIII. yüzyılda Fransız rationalisme'ine (akılcılığına) dayanan kurallı yazının etkisi çok büyük oldu. Roman yazarı Wieland'ın yapitlariyle de rokoko üslubu doruğa varmıştı. Goethe, başlangıçta, bu üslubun etkisi altında kaldı. Ama sonra, giderek bunu yenmeye çalıştı ve yeni bir çığıra gird: Onun yapıtları, üslup bakımından üç evrede irdelenmektedir:

1. Gençlik çağında: Sturm und Drang evresi.

2. Olgunluk çağında: Klasik evresi.

3. Yaşlılık çağında: Romantik evresi.

\section{Sturm Und Drang}

Dilimize "Frrtına ve Atılım" diye çevrilen Sturm und Drang (Gençlik evresi) onun "coşkunluk ve taşkınlık" evresidir: Goethe'nin. oluşumunun ve gelişiminin başlangıcı sayılmaktadır. Goethe bu evresinde, Rhein (Ren) ve Lahn (Lân) ırmaklarının çerçevelediği bölgede dolaşır. Ufukta gotik katedrallerle Ortaçağın yüksek kaleleri vardıs. Goethe burada heyecanlıdır, çoşkundur, firtınalardan ürkmez; kılavuzu Shakespeare'dir. Onun gibi kendisini doğaya vermiştir. Tiyatro dünyasına da doğayı o, bu evrede sokmuş̧tur; dünya repertuvarını adım adım izler ve çeşitli rollerde kendisini bilinçli olarak denemeye çalışır. Gösteriler, onun için uygulamalı tiyatro 
çalışmalarının okuludur. Goethè, burada tiyatroculuk alanında, dört yetisini birden geliștirmeye çalıştı:

1- Oyun yazarlı̆̆ında,

2. Oyun yöneticiliğginde,

3: Oyunculukta,

4. Sahne işciliğinde.

\section{Oyunyazarlığı}

Goethe'nin en büyük isteği yazar olmaktı. Bir Üniversite arkadaşına gönderdiği mektupta şöyle yazmıştır:

"İi bir yazar olmak için, ateşli kafam ile umudum, iyilik gösterilerini onaylamayn engelliyor. Tanr, acaba yazar olmam istemiyor mu?"'2

Goethe'nin bu sözünden, erkenden, hem de çok açı olarak, yaşaminda yürüyebileceği iki yol olduğu bilincine vardığı anlaşı1ıor:

1- Yaşamını, ya bir hizmet görevinde hep istenilen bir işe adamak,

2- Ya da gözlemci olarak, dünya zenginliğini içine alarak kendi yaratıcılı̆̆ında, aldıklarını bir biçime, sanatlı bir biçime sokarak dışarıya yansitmak.

\section{Oyunlarn:}

Goethe'nin yazdıkları arasında ilk oyunları yok olmuştur. Hepsini ya kendisi yok etmiş, ya da yarım kaldığı için yok edilmiştir. . Ancak; çok sonraları, araştırmalar sonucunda, çoğu bir raslantı olarak' parçaları bulunmuş, bưnlardan da ancak adları öğrenilmiştir :

1- Die königliche Einsiedlerin ("Görkemli Yalnız Kadı")

2- Belsazar (Babilonya'nin son Krali)

3- Der 'Tugendspiegel ("Erdem Aynasi")

4- Die Laune des V'erliebten ("Aşık Olan'ın Huysuzlukları")

5- Die Mitschuldingen ("Suç Ortaklarr").

Yalnız sonuncusu tamdır, bir perdelik komedyadır. Bundan başka da, daha 15 küçük farce (fars) türünden komedyası tamdır. Bunlara iki tane de "şarkılı oyun" eklemek gerekiyor:

224 Kasım 1768 tarihinde, Frankfurt'tan Leipzig'e gönderdiği mektup. 


\section{1- Erwin ile Elmire}

2- Claudine von Villa Bella ("Villa Bella'lı Claudine")

XVIII. yüzyıldan bu yana, Almanya'da "şarkılı oyunlar" çok seviliyordu. Alman operetlerinde başlangıcı oldu bu oyunlar; özellikle düzyazılı metinlerle, önceleri daha çok burlesk (kaba komik), sonraları daha çok duygusal, içlerine aryalar duette'lerin (ikili şarkıların) katıldıkları aşk olayları işlendi.. Frankfurt'da, "Yedi Yıl Savaşları" sırasında, ordu ile yurda gelen Fransız komedyacıları, beraberlerinde Fransız "şarkılıoyunlar" getirmişlerdi: gösterdiler. 1771 yilından bu yana da Marchandsche Topluluğu, Goethe'nin baba evleri yakınında Junghof'da (Gençler Sarayı'nda) Mansigny, Philid or ve Gretry'den Fransiz operalanyle Beethoven'in Bonn'daki öğretmeni Neefe, Hiller'den, Benda'dan ve Johann Andre'den Alman "şarkilıoy nlar" verdirtti. Andre de Goethe'nin bestecisi oldu. Kendisi Goethe'den sekiz yaş büyüktü. "Çömlekçi" diye çevrilen Potier adındaki opereti, Goethe'nin çok hoşuna gitmişti. Nasil olduysa oldu, "tiyatroyu çok sevdiği için" dediler, Goethe, onunla tanıştı. Sahne eserlerinin her türünü denemek hevesinde olduğundan, bu besteci ile birlikte "şarkıhoyun" yaratmak üzere ilişki kurdu. Böylelikle de onun Erwin ile Elmire adlı şarkılıoyunu sahneye çktı ve çok beğenilen bir oyun oldu.

Villa Bella'lı Claudinè ise daha ağırbaşlı, acı şarkılı bir komedyadır; çok değerli olduğu halde pek tutunmamıştır, bağımsızlığa özgürlüğe bir çağnıdır bu. Tutucı. Dine bağımlılık, aşkın zorundan kurtulmak gerek! Toplumun ahlak anlayışi, kahramanı sıkmaktadır. Onun güvendiği yalnız bir şey vardır, o da kitarıdır; yalnızlığının, duygularının oyuncağıdır. Ama aslında, oyunda duygulardan öylesine çok söz edilmez.

Goethe, yüksek öğrenimini Strassburg'da tamamladı. Burada devrin büyük yazarlanndan Gottfried von Herder ile tanıştı. Herder, ona Shakespeare dünyasını açtı ve ona verimli bir yaratıcılığa yönelmesini sağladı. Shakespeare ile Goethe, Fransızların akılcı ve kuralcı etkisinden kurtuldu, Alman Tiyatrosu'na da gerekli olan boyutları göstermeye çalıştı. Etkisi, Götz von Berlichingen adlı büyük dramının daha ilk taslağında görüldü. Götz, yerli bir kạhraman- 
'dır, ama tarihin büyük bir kişisi değildir. Goethe, onu "büyük" yapmak, hak uğruna çarpışan, ezilenleri koruyan, halkın dostu, bir "büyük" yapmak, hern de "şarkıll oyun" yapmak istemiştir. Ama, sonra o, bu düşüncesinden vazgeçerek Shakespeare'in etkisi altında, Sokrates'in "zaman., mekan ve eylem birliği"nden ayrılarak yazmak istemiştir. Shakespeare'de de bir deus ex machina (birdenbire çıkarak çözüm için gelen bir Tanrı) yoktur, diyerek, bildiğimiz bu oyunu özgürce tamamlamıştır. Goethe ile Weislingen arasındaki dostluk ile gerilimde, onun, Shakespeare'in Caesar ile Antonius'una, Adelheit için Gleopatrasına, Maria için Octavia'sına, Liebetraut için de Shakespeare'in kendisine baktığını söylediler. Ama, Shakespeare'in kişilerine hiç benzemeyen nitelikleri vardı her birinin, bunlar da, olmaları gerek niteliklerdir; yurdunun hakiki kişileri, Frank ve Schwab bölgelerinin nitelikleridir. Goethe, Herder'e bu ilk taslağını. okuduğunda: "Shakespeare, sizi hepten bozmuş!" deyince ${ }^{3}$, Goethe taslağı yeniden ele alır ve sahne için tam "görülebilecek bir oyun" yapar: (Ein Schauspiel) bu ad da, tamamlar: Götz von Berlichingen mit der eisernen Hand ("Demirelli Berlichen'li Götz") demiştir. Sahneler, oldukça sıklaştırılmış kabalıklar giderilmiş, ağırlık da başoyuncu Götz'e verilmiştir. Oyun, ilk kez Berlin'de 1774 yılında Koch Topluluğu tarafindan Komödienhaus (Komedya- Evi'nde) oynanan Goethe'nin ilk bütük dramı oldu.

Goethe'nin bu yıllarda yazdığı ikinci büyük drämı Clavigo'dur. Kanıṣına ihanet eden "erkeğin bir başkasına olan aşkı" dünya yazınında en büyük konular arasindadır. Goethe, bu konuyu, Fransız yazarlarından Beaumarchais'nin Memoires'inda ("Anular1"1nda) buldu. Günün birinde de bunu dostlar ve gençkızlardan oluşmuş bir çevreye okumuş, içlerinden, anne ve babasının kendilerine gelin olmalarını istedikleri ondokuz yaşındaki kızçağız, Goethe'ye bu konuyu dramatize etmesini söyler. Goethe de oturur, bir hafta içinde bu konuyu işler. Ona hiç de zor gelmemiştir bu konuyu işlemek; çünkü kaynak önündeydi. Beaumarchais: "İspanyolların, Fransızlar karşısında insan haklarını hiç saymadıklarını" yazmıstı. $\mathrm{O}$, bu insanca babasının önerisi üzerine, kızkardeşini desteklemek üzere, onu düğünden önce iki kez bırakan bir İspanyol yazar ile görüşmek için Madrit'e gittiğinde varmış. Evlenmek için verdiği sözü kıran da Clavigo'dur. Goethe, düğümün bağlanışından yola çıtı ama çözmedi. Beaumarchais ile Clavigo arasında geçen büyük sahneyi,

3 13-20 Mayls 1774'de. Dichiung und Wahrheit, 15. Kitapta, Goethe kendisi anlatir. 
Goethe, sözcük sözcügüne çevirir ve tüm ikinci perdeyi, Clavigo'nun "hain sensin!" deyişine kadar doldurur. Ondan sonra da olayl, acı bir "son" ile bitirir. Karakterleri çok değiştirmiştir: Goethe'nin Clavigo'su çok daha soyludur, Marie de çok daha yumuşak, halâ da nişanlısını sevmektedir. Onun Beaumarchais'si de çok daha geniş görüşlüdür. Carlos'unun özgür düşünceleri ve dostluğu da, tamamiyle Goethe'nindir.

Goethe'nin Sturm und Drang evresinin üçüncü büyük dramı da Stella'dır. Bu oyun, iyi oynandığında, özel bir biçimde insanı büyüler; etkisi olayda değil, olayın havasındadır; bu havası da "aşk"tır. Aşk, dünyadır oyunda. İşgününü temsil eden, postahaneye gelen mektupları postacılara dağıtan postahanedeki kadın memur (Postmeisterin) şöyle der:

"Bizim ağlamak için, ne yazık ki, dua etmekten çok daha az vaktimiz var. Yalnız pazar ve işgünlerinde ağlarız biz. "Bir kez de dinlcnmeye koyuldum mu, her şey dinlenir!" (I, 1)

Ama, gene de bu oyunu oynayanlara her gün bayramdır, "duygu bayramı"dır. Bunun için de işte oyuna kendilerini verir seyirciler. Stella oyununu yazmadan bir yıl önce de Goethe, şöyle demişti:

"Bir ân yöneten, evet, tüm ânlarn yöneten, yalnzzca yürektir".

Ama "yürek" huzursuzdur; kendisini tanımaz; kendisini koyuverir, yitirir. Kararsız olan, aşık olan Fernando'dur; ama, onun tüm duyguları, hırsları, kendilerini, Stella'da gösterir. Bıraktığı karısı Cacilie de, ondaki kararsızlığını gösterir. Hep yeniden zevk ałabilmek için Fernando'nun özgürlüğe duyduğu istek, ruhunun bir anında, bu mutluluğu her zaman için sağlar. Duyguların iki kadın arasında, önce birine sonra da ötekine kayması, Fernando'nun her birine beslediği hakiki özlemini vurgular; ama onun duyguları karmakarışik dalgalanır. Oyun da bu dalgalanıştadır.

\section{Olgunluk Çağı: Klâsik Evresi}

Thüringen bölgesinin başkenti olan Weimar'da, sikıc1 bir hava esiyordu; içine aldığı sert esintilerden sonra, Goethe için uzun bir solukverme zamanı gelmişti. Gerçi bu kent küçüktü, ama bir sanat merkeziydi. Henüz daha çocukluğunu yaşayan bir. Dük Karl August ile annesi Anna Amalia tarafindan yönetiliyordu. Ama, gerçekte, burdaki yaşamı uyandıran, uyandırdığı yaşama da biçim 
veren Goethe idi. Burada Gezici topluluklarindan Seyler-Ekhof Topluluğu vardı. 1774 yılında Weimar Sarayı yanınca, bu topluluk geldiği yere, Thüringen ormanının eteğindeki Gotha ilçesine döndü. Weimar'da Sanat severler, bir topluluk halinde, Saray Avcısı Hauptmann'ın evinde, amatörce gösteriler veriyordu. Anna Amalie, küçük Dük'ün eğitilmesi için Goethe'yi Weimar'a çağırmıştı. Çocuk yetiştikten sonra, Goethe, hem. Dük'e devlet işlerinde yardımcı olacak, hem de "Tiyatroseverler Topluluğu"nun başına geçecekti. Geçtiğini duyan "Seyler-Ekhof Topluluğu", Goethe'ye yardımcı olmak üzere Weimar'a geri koştu.. "Sanatseverler Toplüluğu"nun profesyonel tiyatro yaşamı da, Goethe, onun başına geçtikten sonra başlar: Rejisör, oyuncu ve başoyuncu olarak çalışmaya başladıktan sonra, oyunlar, sanat düzeyine yükselir. Goethe o zamanlar, meslekten tiyatrocuları da gerektiği gibi yetişmiş bulmadığından, her birinin eğitilmelerini, kültürlerini artırmalarını ister. Bunun için de oyunculara şunu söyler:

“Homeros'un, Sophokles'in, Euripides'in, Aristophanes'in, Plautus'un, Terentius'un, Shakespeare'in doğa anlayısına gelebilmeleri için, onlann okullarnda yetişmelisiniz! Her şeyden önce de özel eğitici yöntemle doğayn inceleyip öğrenmelisiniz! Oyuncularn her biri, tüm yasamları boyunca, söyleyecekleri büyük duygular için yetişmeli!"'4

Goethe, Saray Orkestrası'rıdan birkaç yaylı sazsanatçısı ile sessanatcısı aldı. Bunların arasında meslekten yetişmiş, Leipzig de tanıdığı ünlü sessanatçısı Corona Schröter de vardı. Güzelliği, çekiciliği, davranışı ve yürüyüşüyle herkesi etkiliyordu. Sahne tekniğinde de, çok dürüst çalışan bir tiyatro ustası olan Mieding yardım etti. Önce, "Seyler-Ekhof Topluluğu"nda göstermişti Mieding kendini. Goethe'nin yanına gelince de, hemen, Hauptmann'ın evinde portatif bir sahne kurdu: "Serbest duran, kısa bir zamanda değiştirilebilen yeni bir biçimde sahneydi bu."5

Weimar çevresinin tiyatro dostları, Goethe, "Tiyatroseverler Topluluğu"nun başına geçergeçmez, çabucak arttı, hem de öylesine ki, Hauptmann'ın evi, seyirciler için artık yetmez olmuştu. Bu yüzden de başka bir özel eve taşınmak zorunda kaldılar; besteci Secken-

4 Müller: "Genaue Nachrichten von beiden K.K. Schaubühnen". Frankfurter Gelehrten -Anzeiger, 1722.

5 H. Kindermann: Theatergschichte der Goethezeit a.a.o. S. 569. 
dorff'un evini çok daha geniş buldular. Seckendorff, müzik ustasi olduğundan buradaki gösteriler, "şarkılı oyunlara" yöneldi. İlk olarak da Goethe'nin Ferry ve Bathely adlı oyunu sahnelendi. Bunda, Corona Schröter, Batthely rolünü oynadı. Goethe, bu oyunu, bir yıl önce yaptığı İsviçre gezisinden getirmişti (1779'de). Günlüğünde, kendisi bu oyundan şöyle söz eder:

"Bunun iģinde estivilen dă̆ havasını ben, hâlâ, kişiler sahneye Łıktıklarnnda, panodaki, kavakli kayalarn arasinda duyuyorum".

Goethe, "şarkılı oyun"ları sahnelerken, bu tür için bir çok önerilerde bulunmuştur. Yazdıklarının arasında en önemlisi de, müzik uygulanırken yaptığı örneklerdir:

"Müziğin söze eșlik etmesinde, aşırılığa kaçınılmamasını öneririm... Ölçü zenginlik verir. Bu işin unsurlar, iki keman, bir viola ve bir basla, bütün bir yayl sazlar takımından daha iyi sonuc almışlardır. Solunum sazlar kullananlar, zevk verebilmek için ardiardinca üflemeliler... Bir yerde flüt, bir başka yerde fago, flavtc, bu zevki sağlar. Insan da o zaman, neden zevk aldığın bilir. Ahçlların sofraya getirip herkesin önünde koyduklar et, balık ve sebzeden oluşmus yemeğin, ister kizarmıs, ister pişmis olsun, karmakarnşık bir tat verir; gens besteciler de böyle davranirlarsa, doğru olmaz!"

Nisan ayında, Thüringen Ormanı'nın içinde, vaktiyle halk ozanlarının yarıştıkları, XVIII. yüzyılda da Karl August'un bir av köşkü olan Ettersburg'da, Goethe, sahne için hazırladığı Aristophanes'in Kuşlar'ını müzikli vermek yürekliliğini de göstermiştir.

1780 yllında, (Komödienhaus), yeni bir "Tiyatro Evi" kurulmuştu Weimar'da. Bu kuruluştan sonra, bu kentte, "Tiyatroseverler Topluluğu"nun başarıları doruğa çıkar. Gösteriler, daha seyrek verilmeye basşlanır, ama daha şanlı olur. Yeni Wittumspalais'nin (Wittumsarayı'nın) karşssında bulunan, Redoutenhaus'un (Törenevi'nin) sahnesi de giderek tiyatro için küllanılmaya başlanır. Olanaklar, böylesine sağlandığı halde, Dük, artık devletişleri yüzünden, öyle pek ilgilenemez olur. Goethe ise, yönetimi altında, unutulmayacak oyunlar sahnelemeyi sürdürür. Bunlar, sonraki tiyatro gelişmeleri için çok yararlı olur. Komödienhaus'da, genellikle sevilen "Gölge Oyunları" da 'gösterilir. İlk olarak da Seckenhoff'un Das Urteil des Midas ("Midas'ın Kararı") çok alkış toplar. 
Weimar'a yakın Tiefurt Parki'nda, açıkhava'da oynanan Goethe'nin Die Fischerin ("Balıkçı Kadın") adlı "şarkılı oyunu" ise çığır açı" bir nitelik kazand. Temmuz 1782 'de oynanan bu oyunun ikinci başlığ: "Bir Orman ve Su oyunu"dur. Corona Schröter, bu oyunda, Dörtchen rolünü oynadı. Açıkhava'da oynanan bu oyunun müziğini de Schröder, kendisi bestelemişti. Yükseğe uzanan ağaçların altında, İlm ırmağı'nın dik yamaçlarının ötesinde, gece karanlığını aydınlatan meşale ışıları içinde, Goethe'nin Park-Tiyatrosu, şaşırtıcı bir estetikle, çok güzel bir açıkhava oyunu çıkardı. Goethe, kendisi, 1807 yllında, bu oyunu şöyle anlatmıştıx:

"Balıķı Kadnn" oyunu, yaz gecesindè, göğün prrıl pırnl, binlerce yıldizinn altında, bülbül şakımalarn if̧inde seslendirildi. Az sonra da bunlara, Schröter'in tatle ve büyüleyici etkili titreşimleri katıldı: 'At üstünde, böylesine ges vakitte, gecenin, rüzgârm içinden, dörtnala giden kimdir?" şarkısinı sörlledi."6

Seyirciler, sahneyi, saman kulübesi'nde seyrettiklerinden, dekor olarak, hem İlm ırmağının bir kıysını, hem de irmağın kendisini görüyorlard1. Geceyarısı, suların üstünde 1şıklarını yansıtan bir kayık da oynaşıyordu. Oyunun kahramanı kızcağız, kaçıp, ırmak boyunca, önce yaya yürüdü, sonra koşarak kayığa bindi. Onu arayanların, nişanlısı, babasi ve komşuları, ellerinde fenerler ve meşalelerle, ışık cümbüşüne katılmaları, çok görkemli bir görünüm sağladı.

"Meşaleler, önce, Koro'nun her yanını aydınlattı, sonra da insanların, kaynaşan kalabalığına katzldi. Gecenin karalığında, binlerce ışık parlayınca, yukarıya doğru tırmanan alevlerin i̧̧inden Kiz'ın, "yetişin!" çı̆̆lığı, İlm ırmă̆ının stra dalgaları içine yansidi, herkese de büyüleyerek sarsan bir an yaşattı."7

Goethe, burada, geceyarısı, "açıkhava tiyatro"sunda bu "şarkılı oyun"unu sergilemekle, söz müzik, ışı, doğa dekoru, oyun bütününü tamamlamış oldu. Oyun. da, bir perimasalı havasına büründü. Irmak ve orman, büyü öğeleri olarak oyunun içine çekilmişti. Bu denemede, doğanın karanlık 'görünümü içinde, koyu karanlığa getirile.ı 1şık oyunları, plastik müzikál biçimde, büyü ögesi olarak kullanma yöntemini getirdi. Sonraları da, Goethe'nin klasik tiyatro sahnelemelerini de etkiledi.

6 Goethe'nin Erlkönig baladı: "Wer reitet so spat durch Nacht und Wind..."

7 G. Jacobi'ye yazdığı bir -mektupta. 
Weimar Dükü Carl August ile Goethe'nin devlet işleri giderek daha çok artar, ikisi de tiyatro alaninda artık çalışamaz olurlar: boş zamanları da giderek darlaşır, "Tiyatrosevenler"'in oyunları için hemen hiç, vakit ayıramaz olurlar. Bu yüzden de bir ara, çok parlak oynanan oyunların arkası kesilir; çalışmalar bir süre durur. Ama, sonra, Goethe, Weimar Saray-Tiyatrosu'nun başına geçirilir.

Goethe, 1791 yılında Weimar Tiyatrosu'nun başına geçti. Yönetici olarak ilk düşündüğü üslup eğitimi idi. Büyük hayaller peşinde koşmuyor, işini yavaş yavaş ilerletiyordu. 2 Saray, yardım için yanına üç kişi verdi:

1- Hesap işleri danışmanı,

2- Müzik işleri için bir orkestraşefi,

3- Reji sorunları için de, Prag'dan bir oyuncu.

"Bellomo Topluluğu"ndan Goethe bir kaç kişi de aldı.

Başlangıçta bu topluluk, orta derecede bir topluluktu; yalın dramlar oynadığı gibi, şarkılı oyunlar ve operalara da yer veriyordu. $\mathrm{K}_{\text {Iş }}$ oyunlarını Weimar'da, yaz oyunlarını da Lauchstadt, Halle, Erfurt ve Leipzig kentlerinde gösterdiler.

.Vulpius: Bellomo Topluluğu'ndan gelmişti, orada tiyatro yazan olarak çalışıordu.

Georg Melchior, ile K ra us da: Goethe'yi sahne dekoru ve kostüm alanında destekliyordu. Kendisi Weimar'da Resim Okulu'nda çalışıyor ve bir "Moda Gazetesi" yayınlıyordu. Bundan ötürü de önerileri tutarliydi.

Corona Schröter : Genç oyuncuları yetiştiriyor,

Aulhorn - : Dans öğretiyor,

Kirsch de : Maç ustası olarak maç derslerini üstlenmiştir.

Goethe, bu orta derecedeki topluluğu, sağlam bir eğitimden geçirdi, sonunda da, dünya çapında önemli oyunlar șergilemeyi başardı. Repertuvarına ilk olarak Schiller ile kendi oyunlarmı ald. Weimar Saray Tiyatrosu'nu da, 7 Mayis 1791 tarihinde Iffland'n Fager ("Avcr") adlı oyuniyle açtı. Kendisi de bu oyun için bir prolog yazmıştı: Prolog'unda: "bütün oyunun uyumu"ndan ve "güzel 
bütün"den söz etmişti, estetik amaçtan konuşuyordu. Bu amaç Winckelmann'ın estetik görüşüyle de uygunluk gösteriyordu. Oyunda, Schröter'in "doğa" ve "doğal'olma" çabası, ayni zamanda da Mannheim Tiyatrosu'nun effekt oyunlarına alı̧̧1mış oldu. Bu da çok önemli bir adımdı.

"Güzel bütün"ün amacı, "güçlükle atlatılabilen bir engel" diye karşılandı. Goethe, buna Rhytmophobie (hastalıklı korku) adını verdi. Tiyatroda da: uyäktan (kafiyeden), düzenden (rhytim'den ürkme anlamına geliyordu. "Sturm und Drang" dram!, bilinçli olarak Fransiz Alexandrin'lerinden ve onu pathos'lu (heyecanli) oyunundan uzaklaşmış, düzyazıya geçmişti. Şimdi ise gene dizeler isteniyor, manzum dram sözkonusu oluyordu; çünkü yüksek üslup ancak dizelerle verilebilecekti. Alexandrin'ler de Alman diline yabancıyd. Bunun için, dile uyan, yeni bir dize düzeninin bulunması gerekiyordu. Jambus'lu (v-) dizelerin dokusu, Alman diline uyuyordu. O halde, bir kez de Jambusları denemek gerekiyordu. Goethe için bir dev çalışma oldu bu. Dizelerden ürken oyuncular, gene dizeli konuşmaya ve dizelere uygun üsluplaştırılan bir oyun tarzına götürüldụ̈ler. Goethe, çoğu provalarda bulunuyor, konuşmaları, durmadan kesmek ve düzeltmek zorunda kalıyordu. Onun müzik yardımcısı Eberwein, Goethe'nin provalarını şöyle anlatır:

"Goethe, salonda, parterre'de, en ufak localarn birinde oturur ve düzeltmelerini 'yüksek sesle yapardi. Parterre'in derinliklerivden Goethe'nin sesi, en yetenekli oyuncunun ses gücünü, dolgunluğgnu ve saydamlığın aşı̆trğndon, onu öylesine dinlerdi ki!... Bunun için de söyledikleri dinlenir, etkiler ve herkese, yüksek bir yasa gibi gelirdi."8

Goethe'yi canlandıran da, sözlerinin dinlenmesiydi. Tüm amaç, oyun sanatında yeni kurallar bullmaktı. Ama, bulacağı kurallar ọyle kurallar olmalıyäı ki, oyuncuları dıştan değil, içten, organik, kendi sanat deneylerinden çıkartacakları kurallar olacaktı. İlk zamanlarda o, çlldıracak gibi olmus; hem de öylesine ki, tiyatro yöneticiliğini bırakmak bile istemiş; çünkü oyuncular, bir türlü, "Sturm und Drang"cıların alışkanlıklarından, karakteristik olanı verme şemasını aşamıyorlarmış. Gerçi Goethe de, vaktiyle, Shakespeare gününde Mannheim'de verdiği söylevde, karakteristik olanın üstünde durmuştu; Schröter de karak-

8 Goethes Schauspieler und Musiker. Erinnerungen von Everwein und Lobe, mit Ergänzungen von Bode. Berlin 1912.' 
tẹistik olanı, örnek olabilecek biçimde gerçekleştirmişti; oynarken, ama, kuşaklar değişmişti artık. Gelişme şöyle oldu: Fransızlara bakan Neuberin'in pathos'u' ve tip oyunu, Eckhof ile karakteristik olana dönüştü. Schröter ile de, doğal, hakiki karakter belirtilerek oynandı. Goethe de şimdi, "öz olanu" istiyordu (das Wesensmässige).. Bu da çok güç atılacak bir adımdı. Bir kez, "bireyden de öz olanı" istiyordu (Individual-Einmalig). Her şeyin ardında sezilen anabiçim'in oynanmasinı istiyordu ('Urform'un). Bunu Goethe'nin oyuncular1 arasında başaracak, ancak bir kişi vard, o da Christiane idi.

Christiane Neumann-Becker. 1791 yllında, Shakespeare'in "King Fohn" adlı oyununda oynamış ve başarı kazanmıştı. O zamandan bu yana da Goethe, ondan çok yararlandı Onu, topluluğunun yürütücü gücü yapts. Christiane de, topluluktaki oyuncularından birini, Goethe'nin ilkelerine göre yetiştirdi. Bu da gene ayni oyun üslûbunu başka oyunculara öğretti. Goethe, Christiana Neumann'dan, onun "King fohn" rolündeki başarısından söz ederken, hep şöyle diyordu:

"Öteki oyuncuların, ona uyum sağlamaları da, hep benim işim oluyordu!"

Bu da gene provalar yapılırken, ilk başarısını Goethe, 1972'de, Weimar'da, ilk' kez oynanan Schiller'in Don Carlos'u ile gösterdi. ${ }^{2}$ Bununla da klâsik oyunlarının üslûbunu bulmuş oldu.

Weimar Tiyatrosu'nun oyuncuları, sonunda, Goethe'nin rejisörlükteki isteklerinin, ne yalnız "kuram", ne de gerçekleşmesi olanaksız "hayal" olduğunu kavradılar. Goethe. Dalberg ile İffland'ın ulaştıkları ereği, çok önemli bir noktada aşmıştı:

Dalberg: Mannheim'de ratio (akıl yönünden bir üsluplaştır- maya doğru yürümüsştü.

Iffland: Berlin'de, Dalberg'in çabalarını, ince, organik, mozaikimsi bir işleyiş biçimiyle, ikinci derecedeki çizgileri biraraya getirerek insan portresinin kişiliğini bir bütün olarak veriyordu.

Goethe ise: Organik bütünlüğü içinde sanatlı üslûbu gerçekleştirmeye çalışıyordu. "Akıl" ile "duygu", "hayal" ile "gerçek" birbirleriyle dengeli birleşecek ve organik bütünlüğü içinde değişerek gelişecekti. 
Goethe için, oyuncuları, sistematik bir eğitime bağımlı tutmak onlanı "Organik rol biçinlendirmesi"ne doğru götürmek, demekti (Organik der Rollengestaltung); bu da sahne biçimlendirmesinde seyircilere, içten gelişmeyi göstermek oldu. Aslında bu. "yapıbilim" (morpholojik) bir düşünceydi, Oyunun biçim d:ğiştirmelerine bir erek koymaktı. Bu düşünce, Goethe'yi, Iffland'nn Weimar'da ilk konuk oyunundan bu yana hep uğraşırmıştır. Bunun için de işte, Mannheim'lilerin hâlâ. "Sturm und Drang" üslupları karşısında, İffland için çok dikkati çeken bir söz söylemiş: Dezent im feinsten Sinne ("en ince anlamda eaepli") demiştir.

1797 yllnda, Mannherm'de Iffland'ın, Beck' in ve Beil'in yanında yetişmiş çok yetenekli genç bir kadın oyuncu: Ka roline Jag emann, Weimar Saray Tiyatrosu için kazanıldı: Âşık rollerini oynayacak soprano sesliydi. Mannheim'de gördüğü öğrenim ile de, Goethe'nin isteklerini en iyi bir biçimde gerçekleştırebiliyordu. Goethe, onun provalarinda bulunuyor, kendisini koruyordu. Ilk olarak Weimar Saray sahnesı'nde Wranitzky'nin Oberon adlı operasinda, Oberon rolünü oynadı. Sahnede görünür görünmez de Weimar seyircisinin çok sevilen bir sahne sanatçısı oldu. Müzik ustası Eberwein, anılarında, onun için şöyle demiştir:

"Zagemann, sahnede, bir bulut arabası içinde görünür görünmez, insan, sanki dïnyaya barnş ve seving haberi getirmek üzere göklerden inen bir melek görüyormus gibi oluyordu. Sahneye çıkar çıkmaz $d a$, parladiğından, ona operada, tiyatroda seşitli roller verdiler. ${ }^{\$ 99}$

Mozart'in "Saraydan Kız. Kaçırma" adlı operasında, Konstanze rolünde de Karoline Jagemann, tüm Weimar kentini fethetmişti.

Karoline: Tiyatroda, Goethe'nin istediği biçim değiştirmeyi, müzikle çözümleyerek, rolünde gerçekleştirmesini bilmişti.

Operada da: Müzikli olanı, dramatize ederek oynanmasını da başarıyormuş.

Weimar'da, yeni bir tiyatro yapısını kurulmasiyle, Goethe; tiyatro yönetiminde en parlak dönemini yaşad.. $\mathrm{O}$, bu parlaklığı, oyun dizelgesinde her yeni oyunu alıp denemesi, her yeni oyuna da "klasik üslub"u verebilmesi için tiyatro eğitiminde gösterdiği çaba-

9 V. Maltzahn; Karl von Knebel Jena 1929, S. 84. 
sıyla sürdürebildi. Bir kezinde de o, hesap işleri Danışmanı Kịms'e şöyle yakınmıştır:

"Tiyatrocular, : çok isteksiz derse geliyonlar; her basamakta kendilerini yetişmiş sanyyorlar; onlan yeniliklere yöneltmek öylesine güs ki, her birine, türlü hokkabazliklar yapmak zorunda kaliyorum, azarliyorum bile"'10

Goethe, toplulưgundaki her bir oyuncuyu" çeşitli rollere girebilen oyuncu" (Verwandlungsspieler) olarak yetiştirmek istiyordu.

"Sahnede yalnizca kendisini oynayan oyuncu, sahne sanaţısı değildir. Öz ve biçim bakımından, çeşitli rollere girmeyène, sanaţ̧ı denemez!" diyordu'11

Durmadan değişik roller için de, Goethe'ye, Eckhof ile Lessing'in, doğal olmak ve gerçek görünmek çabalan yetmiyordu. Ona Schröter'in "Strum und Drang" realizmi de uygun gelmiyordu. Bunun için de işte idealleştirecek bir devinim biçimi bulmaya çalışıordu: İdeal olacak, ama gene de doğal etkileyecekti. Goethe'nin görüşüne göre, en önemli olan henüz eksikti: Oyuncuların, yazarların yürüdükleri idealize eden yolda, kendilerini denemelerini istiyordu. Bunun için de işte şöyle yakındı:

"Gerçi Almanva'da, vücutlarnn, düsüncelerini, duygularını gösterebilen, susmasını, duraklamasını, işaret etmesini, ince çekici beden hareketleriyle söylemesini bilen, konuşmalarn, hoşbir pantomimle bütüne bağlayabilen oyuncular var, ama, biz mutlu bir doğallık istiyoruz, oyuncuların yazarlarla birlikte yürüyerek, onlardan ögrenmelerini istiyoruz; yoksa tiyatroya seyir için gelenlerin istedikleri bir çalışma (Übung) yapılmuş olmaz!'12

Bunun için de provalarında, özellikle buna dikkat ediyordu. Fischer'in yerine, anlayışlı Homeros çevirmeni Johann Heinrich Voss gelince, Goethe giderek daha çok provalara katıldı. Okuma Provaları'nı da Goethe kendisi yürütüyordu. Bu yoldaki yöntemini, Hanau'hllar Derneği'nin yöneticisi Carl Caesar Ritter von Leonard'da şöyle açıklar:

"Bana, okuma provalarnnın, kaçamakların önlenebilmesi, rollerin aksamamast, cansiz değil de, gerçek. bir hava içinde oynanabilmesi,

10 Gespräche mit Eckermann: 22 März 1825.

11 Goethe: Wilhelm Meisters Lehrjahre adlı romaninda Jarno'ya açıklatır.

12 ayn romanda. 
... ateşli saldirrcasina değil de temkinli davranulmasi" dilde de itenin ve bozuk olanin giderilmesi ... ayni zamanda, sahne oyunlarna yabancı olan genç oyuncularin yakışık almadı̆̆ halde, kendilerini kaptırdıkları abartmalaraan kurtarmalar için... brrakılmäması gerek gibi geliyor. Bir çoklarna da, okuma provalar,, rollerin ruhuna girebilmeleri için ezbere öğrendiklerini değil, yüreklerinin dillerini dinlettirebilmek için. . bırakılmaz gibi geliyor." 13

Goethe, provalarında, en çok da di 1 ayrımı üzerinde dururmuş; Ince geçişleri (nüance'ları) kesin olarak belirtilmesini istermiş. Geçi̧̧lerin niteliklerini de: "önemini vurgulayarak, "tepki" göstererek, "utanırcasına" ya da "sabırsızcasına", "yarı gülerek", "yumuşakca" ya da "sevimli" olarak, diye not etmiştir.

Eğitimde en önemli bildiği ereği "birbirlerine uyarak" oynamalarinda görüyordu:

"Bakalım onlar yavas yavas uyumlu, sanatlı bir oyuna alıştırabilecek mivim?". diye de zaman zaman yakıniyordu.

Goethe'nin istediği "yıldız" (star) oyunculuk değil, "topluluk" (ensemble). "beraberlik" oyunuydu. Durmadan, crkestrayı örnek gösterirmiş: Oyun Yöneticisi olarak orkestra Şefini... onun orkestrasına, bir tiyatro yöneticisinin oyununa olduğundan çok daha büyük bir güvenle egemen olduğu için de imrenirmiş; çünkü oyuncular, oyunu bozduklarında "içkulaklarıyla duymaz olurlar!" dermiş. Goethe bu görüşünü de şöyle açıklamıştır:

"Eğer en yüksek olana erişilmek istenirse, o zaman "ynldzz" oyunculuk (Virtiosität), dramatik sanattan (oyun sanatzndan) uzak tutulmal. Hic bir ses, diğer sesleri asmamal. Uyum (Harmonie), bütüne egemen olmall"14

Dildeki ayrımlar (nüance'lar) dışında Goethe, Oyuncularına sözcüğün, hep gizli bir müzikle desteklenmesi gerektiğini söylemiştir:

"Jestlere bir ezgi eşlik ettiğinde, nasıl daha kolay ve daha eğitilmiş bir davranıs olursa, oyuncu da, düpedüz yapacağ rolünü, kafasinda bestelemeli ki, kişisel biçimine göre tekdüzen (monoton) mirldarimasın; gerektiği gibi de sesiri değiştiverek, diusşünce inceliğiyle (Takt'la), ölçülï oynasın!'15

13 H. Kindermann: Theatageschichte Europas Bad. V, S. 177.

14 Wilhelm Meisters Lehrjahre.

15 Goethe: Wilhelm Meisters Lehrjahre'de topluluğun en iyi oyuncusu 'S e r l o'dur. 
Goethe için bir de, heceleri iyi, ölçülü söylemek (articulation) çok önemliydi. Bu da ölçülü korıssmayı sağllyordu. Sesi perde perde yükseltmek, en çok öfkelenilecek yerde bile, kendinden geçmemek gerektiğini söylüyordu. Bununla da, sözde ve jestte, her türlü "vecdi" reddediyor ve oyuncularmın bunu anlamalanı istiyordu. Ama, tüm iş̧̧ilikler, "incelikle" görülecekti. Bu da bir soyluluk bir kibarlık veriyordu dialoga (Vornehmheit).

"Incelik, güc öykünülebilen bir şıydir; çok uzun süren bir çalışmayl gerektirir!" diyordu.

Biçim bakımından gurür değildir inceliği veren ... tersine:

"Oniursuz, aşă̆̊ olandan kaçınan, kibardir. Insan, kendisini hiç, unutmamal,; hem kendisine, hem de basskalarına bakalım. Kendisini hiç bağışlamamalı, başkalarına, ne çok ne de az bir şey yapmamalı. Her seyden duygulanır görünmemeli, her şeyden heyecanlanmamali. Hiç bir zaman ivedi davranmamalı; her an kendine egemen olmasinı bılmeli. İcte, istediğince firtınalar kopsun, dişta'dengeyi korumalı. Soylu insar, kendisini, belki bir çok anlarda ilgisiz gösterebilir, ama ince olan hiç bir zamain böyle davranmamalıdır! Insan ince görünmek için, gerçekten ince olmalı!'16

Sahne D e k o r l a r I sorunları için Goeth'ye Heinrich M e y e r yardım ediyordu, bunun için eldeki para çok azdı. Ama Meyer, gene de Geothe'nin isteğine göre çiziyordu dekorları. O zamanlarda, Goethe'nin, sahne dekorlarının görevini ve biçimlerini nasıl tasarladığı, nasıl yargıladı̆̆ı, Meyer'in taslaklarından öğrenilmiştir. ${ }^{17}$ Goethe "Palmir" adlı operayı, Milano'lu tiyatro ressamı Georg F u e n t e s" in görkemli dekoru içinde gördüğünde, Schiller'e şöyle yazar:

"Tiyatro kuruculuğunda çekilen en büyük sikıntı, yapı-sanatının anakuralları kavranıldı̆̆ halde, 'gerekiyor' diyerek onlardan gene de ayrılmaktadır. Yüksek anlamda yapısanatı, ağırbaşlı, să̆lam bir varlık göstermeli. Bu da kurallart incitmeden, çekici olamtyor. Yoksa tiyatroda, her şey çekici olmalı!. Tiyatro yapisı, hem hafif, hem de süslü, çeşitli, görkemli, yüksek soylu olmalı. Dekorlar, genel olarak, en çok da arka planda tablo verilmeli! De-

16 "Wilhelm Meister'in Çıraklık Yılları"nda Serlo'ya söyletir.

17 Goethe'nin, Frankfurt Tiyatrosunu (Schauspielhaus'u) ziyaret etrikten sonra, Schiller'e 14 Agustos 1797 gününde yazdığı mektup. 
korcu, kuruculuğunda kendi isteklerine göre biçimlendirebilen görünüm (manzara) ressamindan daha ileri bir adım atmalı

Dekor ve oyun, Goethe'nin görüşüne göre, ç̧erçevenin resme olan ilişkisi gibi uyumlu olmalı! Her bakımdan da resim, töresel görünmeli! Goethe, Weimar kentindeki gösterilerinin, hep töresel niteliğini vurgulamıştır. $\Theta$, bu töresel niteliğin çeşitli etkenlerin birbirlerini etkileyerek teatral bir sanat yapıtı yaratmakla ancak ortaya çıktığını biliyordu. "Güzellik" ancak estetik bir d e n g e ile verilebilir, bu da simetridir (bạkışım: "tenazür"). Simetri duruktur (statik); oyun da o zaman duruk bir düşünce verir; ama, böyle olmamalı: hareketli figürlerin ve güçlerin, görünebilen somut bir dizginlemesidir bu. Her şey akın halindedir, hiç durmaz. Oyuncularla, bir görünümden ötekine geçerler, gruplaşır gruplaşmaz da, yeni bir alan açmak üzere dağılırlar.

Goethe'nin "güzellik" gereksinmesi, çok aşırıydı. K o s t ü m lere, tarih ya da folklor bakımından bağh kalmak için gösterdiği çaba (özellikle de kadın oyuncularda), sözkonusu olan giysiler, oyunculara yakışmadığında, "ideal güzelliği" bozduğu için hemen değiştirirdi. Goethe, bunun için kadın. oyunculara şöyle demiştir:

"Ulusal ve zamana uygun giysilerden ancak kendizine yakışan seçin!"

"Güzel görünürseniz, seyirciler hoşlantrlar!"

Weimar Topluluğun birçok oyuncuların giysilerini hep GeorgMelchior Klaus çizmiş ama, onun çizimlerinden çoğu yok olmuş. Yalnız Bertuch'un yayınladığı "Günlük Moda Gazetesinde olanlar kalmıştır, bunlar da, Kraus'un giysilerinden bir fikir verebilmiştir. $\mathrm{Bu}$ "Moda Gazetesi", Fransız Moda Gazeteleri'nin karşısında, yerli örneklerle'çıkmayı amaç edinmişti. Weimar'ın rol giysileri ise, öyle pek yalın değil, oldukça görkemliydi.

Weimar Saray Tiyatrosu gösterilerinin çerçevesi dar olduğu halde, törenli oluyordu; çünkü burada, her akşam saat 17,30'da tüm saray halkı, belli bir düzen içinde tiyatroya geliyor, Orkestra Şefi de müziğin başlaması için işaretini veriyordu. Weimar'da, bu "sanat kentinde".o zamanlar, hiç aydın kişiler eksik olmazdı; aslında, soylu düşüncelerin yönettiği, ama öteki seyirci çevrelerinin de isteklerini 
gözönünde bulunduran aristokratik bir tiyatro oldu. Goethe, "oyun dizelgesi"'nin (repertoire'nın), hiç bir zaman ve hiç bir nedenle düşürülmesini istememiştir:

"Kitle, uyandirlmasi geeeken duygular istemiyor, diye uyandirmamak, yanlış bir hoşgörüdür!" demiştir.

Bununla da tiyatrosunda yalnız oyuncuların değil, ayni zamanda seyircilerin de eğitmeni olmak istemiştir. Seyircilerin de sanatta eğitilmeleri gerektiğine inanmıştı.

Goethe'nin oyunculariyle her gün birlikte olması, sonra da Dük Karl August'un Karoline Jagemann ile olan yakınlığı, Viyana soyluları (Patrizier) salonlarında olduğu gibi "büyük dünya"nın girip çıktığı salonlara egemen olan toplumsal bir değerlendirme karşısında kalmamıştı. Weimar Sarayı, gerçi zaman zaman, genç, yetenekli güçleri, kendileri için yetiştiriyordu, dıştan birçok sanatçları da, saray törenlerinde çalışmak üzere Saray’a sokuyordu; yalnız ne var ki, başkaca bir işleri yoktu; ancak, kendi aralarında bir topluluk idiler, saray ölçülerini ve burjuva ölçülerini bilmedikleri için, onlara herkes biraz tuhaf bakıyor, onlar da kedilerini bu saray oyuncularından uzak tutmayı yeğliyorlardı.

Goethe'nin, ilk gelişim evresinden tiyatroculuğunda biçim değiştirmeye dek olan o y u n d i z el g e s i 'ne (repertoire'ına) gözatılacak olursa, bütün oyun türlerinde, eğlendirenlede bile, "iyi oyunlar" arzulandığı görülür; para bakımından çok sıkıntı çektiği halde, paraca yardım edildiğinde bile, hiç bir zaman, yardım edenlere boyun eğmemiştir. Onun çabası, görkemli oyunları sahneye çıkarmak değildi; ama, her oyun, tragedyadan farce'a değin beğinilmesi için "iyi bir oyun" çıkarmaktı; oyunun büyük, hareketli, neşeli, ince ve her halde sağliklı olması, içinde de birde bulunması gerektiği hasta, güçsüz, ağlayan, duyusal olan her şey olduğu gibi, korkunç, iğrenç ve ahlakı inciten oyunları, "oyundizelgesi"ne almadı. Goethe "ben bunlarla, hem oyuncular, hem de seyircileri bozmaktan korkarım" diyordu Eckermann'a. Onun, daha bir evre öncesinde, olumlu duyarlılı̆̆, bu sinırlamada "korkunç" ve "hasta" diyerek atması dikkatı çekmişti.

- Goethe'nin istediği "oyun dizelgesinin" elde edilmesi için, elindekilerini, ancak yavaş yavaş değiştirmekle kazanabilecekti. Başlangıçta, "oyun dizelgesi”'nin hemen yarısı komedyaydı. Ancak, adım adım ağır- 
başlı oyunlarla opera'nın sayısını arttırdı. Bellomo Topluluğu, Weimar'dan gittikten sonra, oyưn mevsiminin ilk üç ayında, 20 yeni oyunun yılda da 40 yeni oyunun hazırlanması gerekiycrdu; çok hizlı bir tempo (ilerleme hrzı) istiyordu bu.. Goetbe, Bellomo Topluluğu'nun dizelgesinden çok az oyun alabilmişti. Öte yandan, seyirci çevresinin darlığı yüzünden, bir oyun, öyle çok tekrarlanamıyordu. Ancak tiyatro mevsiminin sonuna doğru, Goethe'nin yönetiminde, bir ylllk dizelgeye 24 yeni oyun alabilmişti. Ama, bunda, kendi "Sturm und Drang" evresinden hiç bir yapıt yoktu; hepsini kendinden uzak tuttu. Yalnız dram yazarı Johann Anton Leisewitz'in oldukça yumuşak ve dengeli olan Julius von Tarent adlı oyunu, bir ayrıcalık oldu. Bu yüzden de işte Goethe, bir çok yabancı dramlar oynatmak zorunda kalmıştı. Bunların hepsini, önce sahneye konabilecek bir biçime sokuyor ya da uluslaştırıyordu. Marivaux'dan Beaumarchais'ye dek, Rousseau'dan Merciere'e dek, çağdaş burjuva dramlarını da oynattı. Fransız klasiklerini ise hiç oynatmadı. Italyan'lardan Goldoni ile Gozzi'yi sevmişti; bu ikișini sahneye çıkardı. Danimarka'lıların Molière'i olan Holberg'de, oyundizelgesinde yer aldı. Shakespeare'den ise: Hamlet, King Lear, King John, VI. Henvy." ile oyundizelgesini tamamladı. Yerli oyunlardan da daha çok burjuva, ahlak dramları ağır basıyordu. Bir de Götz von Berlichingen'le günlük şövalye oyunları katıldı dizelgeye. Lessing'den ise Minna von Barnhelm ile Emilia Galotti seçildi. Kendi oyunlanndan da Clavigo ile Die Geschwister ("Kardeşler"), ancak mevsimin sonlarma doğru sahnede görülebildi. Schiller"in Die Räuber'i ("Haydutlar"1) Don Carlos'u ve Kabale und Liebe'yi ("Hile ve Sevgi'i). İffland'ın da, konuk olarak gösterdiği oyunları da çok tutundu.

Opera alanında Goethe, İtalyan yapıtlariyle başlamıştı: Cimarosa'nin Teatral Serüveni'nin ve Amfossi'nin yeni barok operası'nda, kusursuz müziğiyle verdiği Circe operasinı sahneye koymuştu. Bunların libretolarını Goethe Almancaya çevirmiş. Alman ve Avusturya operalarını almakla da oldukça büyük bir değişim getirdi. Hepsinin başnda Karl von Diterratorf ile Wolfgang Amadeus Mozart vardı. Goethe'nin kendi" şarkılh oyunu" olan Claudine von Villa Bella'y1 da Reinhardt'm müziğiyle, Weimar'llar seve seve seyrettiler.

Goethe'nin iilk gelişim evresinde oyun dizelgesi için koyduğu ölçüler, onun ikinci klasik evresinde istediği "sağlam" ölçülerle ay- 
nıydı. Bunun için de, yönetici Goethe, sahne uygulamasında, Winckelmann'a giden yolda başarılı oldu. Artık, zamanı geçmiş, diye gördüğü her şeyi, olduğu gibi, her türlü aşırı yeniyi de geride bıraktn. Bu sırada da, çok programl olarak oyun dizelgesinin, her seyircinin kahramaninı karşılayabilmesi için "çok yönlü" olmasına bakıyordu. ${ }^{18}$ Bu yüzden de Goethe'nin oyun dizelgesi, rahat bir dizelge değildi: her kattaki seyirci anlayısını kazanmak, ayni zamanda da ötekilerin gereksinme ufuklarina uzanmak istiyordu.

*

Weimar Saray Tiyatrosu'nun iki etken, klasik üsluba ulaştırdı ve ona dünyaca önem kazandırd.

1- Diştan, Stuttgart'tan getirilen mìmar Thouret ile ressam Haidelhoff'un tiyatro yapısının biçimini değiştirmeleri (1798'de).

2- Tiyatronun dizelgesi yeniden ele alınırken, Schiller'in dramaturgi işlerinde ve oyunların eğitiminde, provalarında, yardımcı clmasi.

Her bakımdan çok beğenilen "yeni yapı", saray halkının önünde törenle açıldı. $\mathrm{Bu}$ açılışı Goethe, şöyle anlatmıştır:

"Yapının oturtuluşu, zevkli, ağırlık vermeden, ağırbaşlı, yüklü olmadan görkemli. Parterre'i içine alan eliptik dikilmis, granit gibi de boyal sütunlar üzerinde, dorik düzen, sütunlarla çevrilmiş². Önünde ve altinda, seyircilerin oturacaklan yerler, bronstan bir merdiven parmaklığiyle ayrnlmıştır. Sütunlar, antik sarı mermerdendir. Başlıklarn ise bronstan; cumba da bir çeşit yeşile bakan kurşunrengi Cipollin'den (2şığz içine çeken mermerden); bunun üzerine, dikeyine sütünlar istüne, çeşitli maskeler konmuştur: trajik, vekarli, komik, gerili, bozuk yüzlere değin, her türlü örneklerden çesitli nitelikler göstermektedirler. Cumbanın ardinda ve üstünde bir galeri daha var. Perde: Her şeyc uygun. Seyirci de: kendisini ve sevdikleri oyuncu topluluğunu, yakın bir zamanda, gerçi küçük, ama hoş olan bu yerde görmek üzere gösteriyi beklecektir"19

Törenli, canlı renklerle süslenmiş olan bu tiyatroyapısı, Schiller'in Wallenstein üçlüsünde Max Piccolomini'nin kostümleri içinde, Voss'un

18 Goethe'nin istediği ölçüler Weimarische Hoftheater adlı yazısında (Schriften zur Literatir: Artemis Vrlg. Bd. 14, S. 62-90.)

19 Dorik: Kalın, kesin oyuklu yuvarlak, altlarinda taban olmayan sütunlar. 
söylediği monologla açıldı. Voss'da, monologunda, sözlerini, yeni yapının "uyumlu yüksek düşün ruhuna", "yaratıcı oyun dehası" ile "yüksek kurallara" surımuş ve tiyatro ile operanın birarada gerçekleşmesini dilemiş.

Weimar'da oynanacak oyunlar için, sahneye koyuş işlerini Goethe, çok belli kurallara dayıyordu. . Söz konusu olan oyunu, oynanabilir, her bakımdan anlaşlabilir bir hale getirecek biçimde işlenmesini istiyordu. Bu tür işlemenin güzel bir örneği, Schillerin Egmont'unu işleyiş biçimiyle verilmiş oldu. Bu örnek, ayni zamanda, Goethe ile Schiller'in birlikte çalışmalarını vermesi de çok önemliydi. Bu çalışmalarda, ikisinin, bundạn sonraki tüm çalı̧malarına yol açtı: Goethe'nin, lirizmi ile dialogları ve düşünce yürütüşünü çokça dallandırıp budaklandırmasıaı, Schiller, teatral enerji ve sağlam bir etki elde edebilmek için geriyordu. Goethe, ozan olarak, gerçi bu dramaturgiyi istemiyordu ama, gene de tam bir tiýatro adamı olan Schiller'e hak vermiyor değildi:

"Schiller, dialogun, en ̧̧ok dramatik olandan idilik ve elejik olana gestiği yerde kusalttyordu; sünkü, bir cyunda, sok şey olabildiği gibi, çok duyulmus olan da söylenebilirdi. Bu yüzden de bir çok hos olan yerleri de çizip geçti." 20

Schiller, bir de dramaturgi bakımından ikinci bir iş yapıyordu. Goethe'nin atladığı, seyircilerin seziş yeteneğine fazlaca yöneldiği yerde, Schiller, nedenli geçitler koyuyordu, Goethe'nin metninde belirsiz olanı imgelediği yerde de, Schiller, halk felsefesinden geldiği, Kant'tan da çok şey öğrendiğinden, görev katılığından ve içzorunluluktan, olumlu olumsuz, belli olanı yerine oturtuyordu. Şöyle ki:

Goethe: Schiller'in Egmont'unu, Richard'in karşısında yakındırır ve şöyle dedirtir: "Bénim istemediğim gibi yaşamamı istiyorlar". Oysa, Schiller'in sahne çalı̧̧malarında bu tümce şöyledir: "Benim yaşamıyacağım gibi yaşamamı istiyorlar."

Ama, Egmont'un operamsı sonundan, Schiller, bunun, seyirciden çok fazla bir şey istemek olduğunu bildiği halde, onnu bırakır; çünkü her ikisi de, Goethe ile Schiller, bunun yeni bir "erek" demek olduğunda ayni düşünceyi taşıyorlardı: Yüksek, ideal dram ile, zamanları aşacak değerde bir tiyatro yasalılığı arasında r:yumluluktu bu. Gerçi bu uyumluluğa, oyunun ilk bölümünde vilaşılmıştır, ama,

20 Cotta Yayınevinin çıkardığı “Allgemeine Zeitung”a anlatır Ekim 1798. 
tam olarak, ayrı ayrı bölümlerin bütününde, açıkça görülebilebilmekti. Şimdi de bu uyumun, oyunun bütününde sağlanması gerekiyordu. Yüksek dramda, teatral zorunluluktu bu, ve ancak Goethe ile Schiller'in birlikte çalışmasiyle gerçekleşebildi. Onları, her ikisinin de arkadaşı olan yazar Karl Philipp Moritz'in göstermiş olduğu önkoşuldán: ses, renk ve hareket birliğinden yola çıtılar.

Goethe ile Schiller, bu Weimar sahnesine, bir çeşit "deneme sahnesi" diye baklyorlardı. Bu sahnenin seyircilerinde, özel bir "fikir aristokrasisi" vard1; seyircilerini de "deneme konuları" olarak alabiliyorlardı. İşte en çok da bu özellik, erkenden bir çok dış ziyaretçileri Weimar'a çekti. Bir çokları Weimar Topluluğu'nun oyunlarını, Lauchstadt'daki konuk oyunlarını seyrettiler. Ama bütün bu oyunlar seyreden Jena ve Halle kentlerinin üniversitelerindeki öğrenciler, erkenden, bu Weimar Tiyatrosu'nun ürününü, Avrupa'nın tüm bölgelerine överek yaydılar.

Goethe 1803 yılında, iki genç oyuncuya Pius Alexander Wolff ile Franz Grünèr'e "Regeln für Schauspieler" ("Oyuncular için Kurallar") adını verdiği kitabını söyleyerek yazdırdı. 1824 yılında da yazar ve özel yazman Johann Peter Eckermann'a bu kuralları yeniden kaleme aldırdı. Son zamana dek, bu kurallardan yalnız Eckermann'a yazdırdıklan biliniyordu; çünkü Eckermann, Goethe'nin yazdırdıkları ile kendi bildiklerini birleştirmiş ve ortaya âdeta "kutsal bir tiyatro kitabı" çıkarmıştı (Theaterkatechismus). Goethe'den de izin alarak, onu yayınlayınca, kitap, oyuncuların ellerinden düşmez oldu. Bu arada, P.A. Wolff ölür. H.G. Böhme de onun ardinda. kalan defterler arasında elyazısı ile Goethe'nin ona yazdırdığı defteri bulur: Weilburg'da bulunduğu için de Weilburg Funde (Weilburg buluntuları') diye adlandırilır. Goethe'nin, oyuncu yetiştirmek için tasarladı̆̆ı planları açıkça göstermesi bakımından önemlidir. Weimar'da oyuncu yetiştirmek için bir de tiyatro kursu açmı̧ Goethe (Tehaterkurs) bu kursu da yönetmiş. O zamanlar, bu kursda aşağı yukarı oniki öğrencisi varmıs. Oyunculuk dersine başladıktan sonra da şöyle demiş:

"Bu güne dek, içimden gelen bir gücle yaptığım bu işi, şimdi, daha açık olarak görmeğe başladım. Kendim için gelistirdiğim grameri, bir çok genç oyuncularla uyguladım. Bunlardan bir kạ̧ı yazılmıştır." 
Kurallar, tam 91 tạe imiş. Hepsini de oyunşanatı için koymuş: "Oyunsanatr: Söz ile gövde deviniminden oluşur. Ama, bunu bir ikilem olarak almamak gerekir; çünkü bunlar iki ayrn kaynaktan geldikleri halde, birarada çalışan, biçimvérici gü̧̧lerdır."

Ne yazık ki bu kurallarm ancak sekiz tanesi biliniyor. Bunlar da şunlardır:

1. Pürüzsüz, şivesiz bir konuşma (dialog). Yöreselliğin sahnede yeri yoktur, aşılmalı!

2. Söylenen, açık söylenmeli $\mathrm{ki}$, seyirciler, söyleneni iyi anlasinlar. Bu da boğumlamak (articuler) ile olur: Heceleri tane tane söylemekle, ciğerlerden g'elen havanın, ağız ve burundaki çeşitli nokta ve bölgelerde engellenerek sesyolunun herhangi bir yerinde daralma ya da kapanma ile sesi keskin çıkartmaktır. Bu olay, söznokta ve bölgelerde engellenerek sesyolunun herhangi bir yerinde daralma ya da kapanma ile sesi keskin çıkartmaktır. Bu olay, șözcüklerin son hecelerini yutturmaz, belirtir. Bir çok oyuncular, bunu mekanik bir biçimde yerine getirdiklerinden, heceler kopar.

Goethe'ye karşı gelen bir oyuncu: Reinhold, Graff'a, 1808 yılında, alayla şöyle demiştir:

"Goethe'nin ektiğgi tohumlar, ürünkaldırma (hasat) zamanında biçilir."

Goethe, kendisi ise bunu başka türlü almıştır:

"Sözler ve tümceler, öylesine söylenmeli ki, anlamı kolayca ve kesinlikle dinleyicileri sarsin!"

1)emek oluyor ki Goethe için oyụnch, "ima" ile, sözleri yorumlayarak değil, açık konuşacaktır.

3. Oyuncunun konuşma biçimini, onun rolüne uyma yeteneği belirleyecektir; öylesine ki, oynayacağı kişinin "havası" (Stimmung) tümce uyumu içinde yansımal. Her tutku, ölüm ürpertisi de, coşkusu içinde canlanmalı.

4. Goethe, konuşmada biçim veren duraklamanın görevini de unutmamıştır: Oyuncular, derin bir soluk almakla söze başlamalı (Stimmeinsatz)- Onun bu önerisi de çok eleştirildi- Oysa, ancak böylelikle zorunlu olan öteki dalgalanmalar verilebilir (Modulation).

5. Anlam birliğin, söyleme ritminde, mutlaka dize ve uyak (kafiye) duraklamaları konmasını isterdi Goethe. 
6. Coşkudan (pathos'dan) vazgeçilmeli! diyordu. Sözler yüksek sesle, abartmalı değil (deklamation olmamalı), daha çok "yüce bir yalınlı" (in erhabene Einfalt) içinde söylenmeli! P.A. Wolff'a yazdığı bir not defterinde Goethe şöyle der:

"Vaktiyle tragedyanın görkemli içinde kabarık, abartılmıs bir konusma biçimi istenirdi. Simdi ise, en yüce olann bile, büyük bir yalınlık içinde söylenmesi gerekiyor. Oyuncuyu söylevciden ayıran da budur."2

7. Oyuncu, oyunun anlam dokusundan çıkan role egemen clacaktir.

8. Bilinen son kural da, "doğru" ve. "güzel" kavramları üzerinedir.

Goethe, oyun sanatının önemini, kişinin sahnede duruşunda tavrinda ve deviniminde bulunur. Bu konudaki önerileri de, onu, ethik ve estetik idealizmin ereklerine, Alman klasisizmine götürmüştür. Goethe'nin isteği :

"Oyuncu düsünmeli, doğayı yalnızca öykünmemeli; ayn zamanda onu ideal olarak tasarlamalı; oyununda doğru olan güzel bir bağlamalı."

$\mathrm{Bu}$ da klâsik icieal insan portresinin oyunda gerçekleştirilmesi demekti.*

* 20 Kasım 1986 yllında, A. U̇. Dil ve Tarih-Coğrafya Fakültesinde, Tiyatro öğrencilerine tarafımdan Konferans olaiak verildi. 